Cite this: Chem. Commun., 2014 , 50,2801

Received 19th December 2013, Accepted 22nd January 2014

DOI: $10.1039 / c 3 c c 49633 c$

www.rsc.org/chemcomm

\section{Copper-catalyzed ortho-C-H amination of protected anilines with secondary amines $\dagger$}

\author{
Ángel Manu Martínez, Nuria Rodríguez, * Ramón Gómez Arrayás* and \\ Juan C. Carretero
}

A practical $\mathrm{Cu}$-catalyzed picolinamide-directed o-amination of anilines showing excellent mono-substitution selectivity and high functional group tolerance has been developed.

The ubiquity of arylamines ${ }^{1}$ among pharmaceuticals, natural products and materials continues to inspire the development of efficient and sustainable methods for the construction of aryl $\mathrm{C}-\mathrm{N}$ bonds. The direct cross-dehydrogenative coupling between arenes and $\mathrm{R}_{2} \mathrm{NH}$ represents an appealing approach ${ }^{2}$ that complements standard procedures for $N$-aryl bond formation relying on pre-activated substrates such as the Ullmann-Goldberg, Buchwald-Hartwig and Chan-Lam aminations. ${ }^{3}$ In this context, the Pd-catalyzed intermolecular amination of arenes with $\mathrm{R}_{2} \mathrm{NH}$ is emerging as an increasingly viable tool. ${ }^{4,5}$

$\mathrm{Cu}$-catalyzed $\mathrm{C}-\mathrm{H}$ amination represents a distinct challenge that has stimulated substantial research effort since the pioneering reaction of 2-phenylpyridine with tosylamide reported by Yu et al. in $2006 .{ }^{6}$ However, most of the reports have focused on intramolecular processes ${ }^{7}$ or base-promoted reactions at acidic $\mathrm{C}-\mathrm{H}$ bonds. ${ }^{8,9}$ In contrast, Cu-catalyzed intermolecular amination of "inert" aryl C-H bonds has been mainly limited to arenes with the non-removable 2-pyridyl directing group. ${ }^{10,11}$ Daugulis's group has recently overcome this limitation and developed a removable directing group strategy for the Cu-catalyzed amination of non-acidic benzamide derivatives assisted by 8 -aminoquinoline and 2-picolinic acid auxiliaries. ${ }^{12}$ Despite this progress, the Cu-catalyzed intermolecular amination of arenes is in its infancy in terms of scope and practicality.

Recently, we have introduced the 2-pyridylsulfonyl group $\left(\mathrm{SO}_{2} \mathrm{Py}\right)$ as an effective $N$-protecting/directing group for the Cu-catalyzed $o-\mathrm{C}-\mathrm{H}$ halogenation of anilines. ${ }^{13}$ Herein we disclose the $\mathrm{Cu}$-catalyzed $o-\mathrm{C}-\mathrm{H}$ amination of aniline derivatives with

Departamento de Química Orgánica, Universidad Autónoma de Madrid, Cantoblanco, 28049 Madrid, Spain. E-mail: n.rodriguez@uam.es,

ramon.gomez@uam.es

$\dagger$ Electronic supplementary information (ESI) available: Experimental procedures and characterization data of new compounds and copies of NMR spectra. See DOI: $10.1039 / \mathrm{c} 3 \mathrm{cc} 49633 \mathrm{c}$ secondary amines using a readily removable 2-picolinic acid directing group. ${ }^{4 g^{-j} j, 12}$

Based on our earlier results, ${ }^{13,14}$ we initially envisioned that the $N-\left(\mathrm{SO}_{2} \mathrm{Py}\right)$ protecting group could assist the Cu-catalyzed intermolecular $o-\mathrm{C}-\mathrm{H}$ amination of anilines. Nonetheless, we observed much higher reactivity when using the closely related $N$-COPy directing group. ${ }^{15}$ The model reaction of picolinamide 1 with morpholine gave traces of the $o$-amination product 2 under conditions similar to those reported by Daugulis: ${ }^{12} \mathrm{Cu}(\mathrm{OAc})_{2^{-}}$ $\mathrm{Ag}_{2} \mathrm{CO}_{3}(25 \mathrm{~mol} \%)$ and $\mathrm{NMO}$ (2.0 equiv.) as an oxidant in NMP or DMSO at $130{ }^{\circ} \mathrm{C}$ for 16 hours (Table 1, entry 1). Just switching the oxidant to $\mathrm{O}_{2}$ led to an encouraging yield of $27 \%$ (entry 2). At this point, some control experiments showed that $\mathrm{Cu}(\mathrm{OAc})_{2}$ was essential (entry 3), whereas $\mathrm{Ag}_{2} \mathrm{CO}_{3}$ could be absent (entry 4). A brief screening of solvents (entries 5-7) revealed that the use of

Table 1 Evaluation of the reaction conditions

\begin{tabular}{|c|c|c|c|c|c|}
\hline & 1 & equiv) & $\begin{array}{l}\mathrm{Ac})_{2} \text {-cat., Oxidant } \\
\text { ive, Solvent }(0.2 \mathrm{M}) \\
, 16 \mathrm{~h}\end{array}$ & & 2 \\
\hline & Oxidant & Additive & Solvent & $T\left[{ }^{\circ} \mathbf{C}\right]$ & Yield $^{a}[\%]$ \\
\hline 1 & NMO & $\mathrm{Ag}_{2} \mathrm{CO}_{3}$ & NMP & 130 & Traces \\
\hline 2 & $\mathrm{O}_{2}(1 \mathrm{~atm})$ & $\mathrm{Ag}_{2} \mathrm{CO}_{3}$ & NMP & 130 & 27 \\
\hline $3^{b}$ & $\mathrm{O}_{2}(1 \mathrm{~atm})$ & $\mathrm{Ag}_{2} \mathrm{CO}_{3}$ & NMP & 130 & - \\
\hline 4 & $\mathrm{O}_{2}(1 \mathrm{~atm})$ & - & NMP & 130 & 23 \\
\hline 5 & $\mathrm{O}_{2}$ (1 atm) & - & DMSO & 130 & 21 \\
\hline 6 & $\mathrm{O}_{2}(1 \mathrm{~atm})$ & - & DMPU & 130 & 30 \\
\hline 7 & $\mathrm{O}_{2}(1 \mathrm{~atm})$ & - & $p$-Xylene & 130 & $48^{c}$ \\
\hline $8^{d}$ & $\mathrm{O}_{2}(1 \mathrm{~atm})$ & - & $p$-Xylene & 130 & $62(60)^{e}$ \\
\hline 9 & $\mathrm{PhI}(\mathrm{OAc})_{2}$ & - & $p$-Xylene & 130 & $85(84)^{e}$ \\
\hline $10^{f}$ & $\mathrm{PhI}(\mathrm{OAc})_{2}$ & - & $p$-Xylene & 130 & $85(83)^{e}$ \\
\hline $11^{f}$ & $\mathrm{PhI}(\mathrm{OAc})_{2}$ & - & $p$-Xylene & 60 & $75(74)^{e}$ \\
\hline
\end{tabular}

Conditions: aniline $1(0.20 \mathrm{mmol})$, morpholine $(0.40 \mathrm{mmol}), \mathrm{Cu}(\mathrm{OAc})_{2}$ (25 mol\%), oxidant (2.0 equiv.), additive ( $25 \mathrm{~mol} \%$ ), solvent $(0.2 \mathrm{M}), 16 \mathrm{~h}$ and $\mathrm{N}_{2} \cdot{ }^{a}$ GC yields $\left(n-\mathrm{C}_{16} \mathrm{H}_{34}\right.$ as internal standard). ${ }^{b}$ In the absence of $\mathrm{Cu}(\mathrm{OAc})_{2} \cdot{ }^{c} 60 \%$ GC yield after $48 \mathrm{~h}$. ${ }^{d}$ Reaction under microwave: $130{ }^{\circ} \mathrm{C} / 150 \mathrm{~W} / 3$ h. ${ }^{e}$ Isolated yield. ${ }^{f} \mathrm{Cu}(\mathrm{OAc})_{2} \quad(15 \mathrm{~mol} \%)$ and $\mathrm{PhI}(\mathrm{OAc})_{2}$ (1.20 equiv.). 
Table 2 Evaluation of the $\mathrm{N}$-directing/protecting group

\begin{tabular}{|c|c|c|c|}
\hline & $\begin{array}{l}\text { Morpholine (2.00 equ } \\
\mathrm{Cu}(\mathrm{OAc})_{2}(20 \mathrm{~mol} \%) \\
p \text {-Xylene }(0.2 \mathrm{M}), 13 \mathrm{C}\end{array}$ & $\underset{2}{(2.00 \text { equiv) }}$ & \\
\hline Entry & PG/R (Substrate) & Product & Yield $^{a}[\%]$ \\
\hline 1 & $\mathrm{C}(\mathrm{O})(2-\mathrm{Py}) / \mathrm{H}(\mathbf{1})$ & 2 & $71(74)^{b}$ \\
\hline 2 & $\mathrm{C}(\mathrm{O})(\mathrm{Ph}) / \mathrm{H}(3)$ & - & $-^{c}$ \\
\hline 3 & $\mathrm{Ac} / \mathrm{H}(4)$ & - & $-^{c}$ \\
\hline 4 & $\mathrm{SO}_{2}(2-\mathrm{Py}) / \mathrm{Me}(5)$ & $9+10^{d}(1: 1)$ & 30 \\
\hline 5 & $\mathrm{H} / \mathrm{H}(7)$ & - & $-^{e}$ \\
\hline 6 & Ts/H (6) & - & $-^{c}$ \\
\hline 7 & $\mathrm{C}(\mathrm{O})(2-\mathrm{Py}) / \mathrm{Me}(\mathbf{8})$ & - & $-^{c}$ \\
\hline $\begin{array}{l}{ }^{a} \text { GC } \\
\text { anilin } \\
\text { mixtu }\end{array}$ & $\begin{array}{l}\mathrm{C}_{16} \mathrm{H}_{34} \text { as inter } \\
\text { ed. }{ }^{d} \mathbf{1 0}=N, N-\end{array}$ & $\begin{array}{l}\text { dard). }{ }^{b} \text { Isolat } \\
\text { pyridine-2-sulf }\end{array}$ & $\begin{array}{l}{ }^{c}{ }^{c} \text { Starting } \\
{ }^{e} \text { Complex }\end{array}$ \\
\hline
\end{tabular}

p-xylene, a non-polar solvent, could increase the yield up to $48 \%$ (entry 7, 60\% upon prolonging the reaction time to 48 hours).

The decisive factor in making the transformation effective was the choice of $\mathrm{PhI}(\mathrm{OAc})_{2}$ as the oxidant (see the $\mathrm{ESI} \dagger$ for further studies). ${ }^{16}$ Full conversion in 16 hours was observed with 2 equivalents of $\mathrm{PhI}(\mathrm{OAc})_{2}$, allowing the desired product 2 to be isolated in $84 \%$ yield (entry 9 ). The loading of both the $\mathrm{Cu}$ catalyst (15 mol\%) and $\mathrm{PhI}(\mathrm{OAc})_{2}$ (1.2 equiv.) could be significantly reduced without an appreciable impact (83\%, entry 10). Moreover, the temperature could be lowered to $60{ }^{\circ} \mathrm{C}$ while maintaining a synthetically useful yield (74\%, entry 11$)$. It is remarkable that no diamination products were detected in the crude mixtures.

A screening of protecting groups confirmed the superiority of the COPy group, emphasizing the cooperative directing role of both $\mathrm{CO}$ and 2-Py moieties (Table 2). The lack of reactivity of benzanilide 3 and acetanilide 4 revealed the importance of the 2-Py unit (entries 2 and 3). However, the coordinating $\mathrm{NH}-\left(\mathrm{SO}_{2} \mathrm{Py}\right)$ substrate 5 afforded, with low conversion, the desired $o$-aminated product 9 accompanied by the $N$-arylated product 10 (1:1 mixture), the latter arising from the reaction of 5 with the iodobenzene generated as a byproduct (entry 4 ). The reaction of the free aniline or its $N$-tosyl derivative was totally unproductive (entries 5 and 6). Finally, $N$-alkylation was not tolerated, the $N(\mathrm{Me})(\mathrm{COPy})$-aniline 8 being recovered unaltered (entry 7).

The reaction of variously substituted aniline derivatives with morpholine is presented in Scheme 1. Substrates with electron-rich ( $\mathrm{Me}$ and $\mathrm{OMe}$ ) and moderately electron-deficient ( $\mathrm{F}, \mathrm{Cl}$ and $\mathrm{Br}$ ) substituents at the $p$-position reacted particularly well (typically $60-81 \%$ yield). Even the strongly coordinating $\mathrm{NMe}_{2}(29,43 \%)$ and the unprotected hydroxymethyl $(32,46 \%)$ groups were tolerated. The complete $o$-selectivity was particularly noteworthy in the $p$-(OMe)- and $p$ - $\left(\mathrm{NMe}_{2}\right)$-aniline derivatives, with two $o$-directing groups. Strongly electron-withdrawing groups, such as $\mathrm{CO}_{2} \mathrm{Me}, \mathrm{CF}_{3}, \mathrm{CN}$ or the base-sensitive COMe group, were compatible but resulted generally in lower yields and required higher loadings of $\mathrm{Cu}(25 \mathrm{~mol} \%)$ and $\mathrm{PhI}(\mathrm{OAc})_{2}$ (2 equiv.). $m$-Substituted substrates reacted generally with complete regiocontrol at the sterically less hindered site (42 and 43). As an exception, the aniline with a $m$-OMe group led to a $2: 1$ mixture

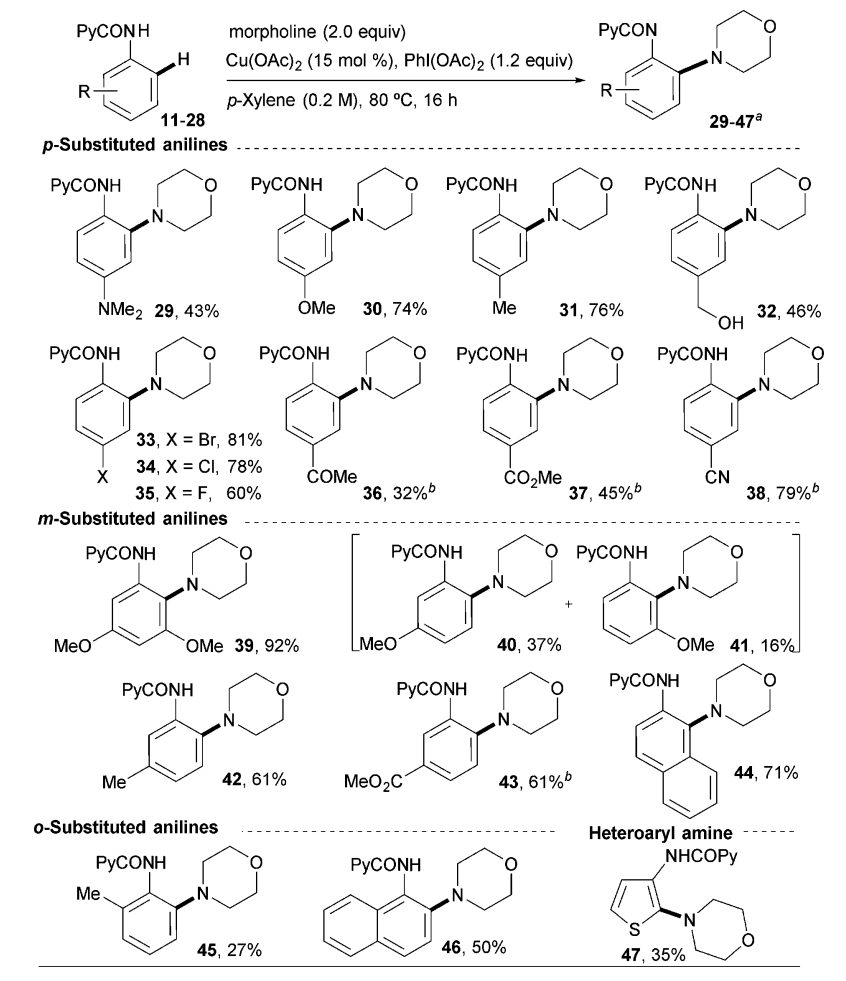

Scheme 1 Cu-catalyzed o-amination of aniline substrates with morpholine. ${ }^{a}$ Isolated yields for products 29-47. ${ }^{b} \mathrm{Cu}(\mathrm{OAc})_{2}$ (25 mol\%) and Phl(OAc) (2.0 equiv.).

of the two mono- $O$-aminated products ( 40 and 41 ). $o$-Substitution led to reduced reactivity $(\mathbf{4 5}, 27 \%$ yield $)$, presumably because of its increased steric requirements, while the 1-naphthyl derivative was aminated at $\mathrm{C} 2(\mathbf{4 6}, 50 \%$ yield $)$. A heteroaromatic amine was also amenable to the reaction, albeit in lower yield $(47,35 \%)$.

Several morpholine, piperidine and piperazine derivatives bearing common functionalities including ethers, esters and nitriles performed well in this reaction (Scheme 2). Unfortunately, simple secondary amines proved to be much less effective (products 56 and 57).

Finally, we demonstrated both the scale-up of the reaction up to 1 gram-scale without loss of yield (see the ESI $\dagger$ for details) and the efficient directing group removal under basic conditions (Scheme 3, product 58, 96\% yield). The resulting 2-morpholinoaniline was next derivatized into the corresponding benzimidazol 59 via an oxidative cyclization reaction. ${ }^{17}$ Although the mechanism is unclear at this point, the lack of reactivity of $\mathbf{1}$ in the presence of radical scavengers such as TEMPO or Galvinoxyl suggests that a SET pathway might operate ${ }^{18}$ (see the ESI $\dagger$ for intramolecular kinetic isotope effect and competition studies).

In summary, we have developed a regioselective $\mathrm{Cu}$-catalyzed ortho-C-H amination process assisted by a removable $\mathrm{N}$-COPy group that provides a straightforward means for the preparation of $o$-aminoaniline derivatives.

We thank the Spanish Government (MINECO, CTQ2012-35790) and the Madrid regional government (AVANCAT, S2009/PPQ-1634) for financial support. N.R. thanks the MICINN for a Ramon y Cajal contract and the Marie Curie Foundation (CIG: CHAAS-304085). 


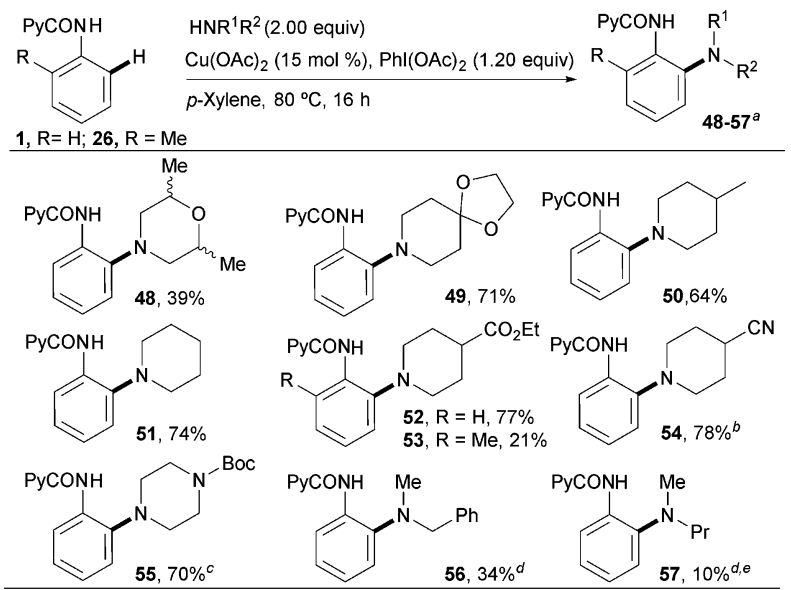

Scheme 2 Scope of the amine counterpart. ${ }^{a}$ Isolated yields for products 48-57. ${ }^{b} p$-Xylene: NMP $(1: 1)(0.2 \mathrm{M}) .{ }^{c} \mathrm{Cu}(\mathrm{OAc})_{2}(25 \mathrm{~mol} \%)$ and $\mathrm{Phl}(\mathrm{OAc})_{2}$ (2.0 equiv.). ${ }^{d}$ Using $\mathrm{O}_{2}(1 \mathrm{~atm})$ instead of $\mathrm{Cu}(\mathrm{OAc})_{2}$. ${ }^{e} \mathrm{GC}$-yield $\left(n \mathrm{C}_{16} \mathrm{H}_{34}\right.$ as the internal standard).

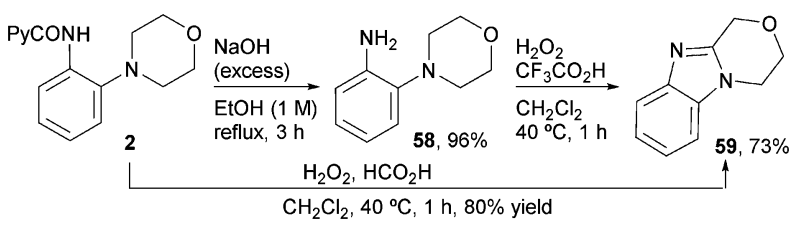

Scheme 3 Deprotection of $\mathbf{2}$ and synthesis of the benzimidazole $\mathbf{5 9}$

\section{Notes and references}

1 Amino Group Chemistry: from Synthesis to Life Sciences, ed. A. Ricci, Wiley-VCH, Weinheim, 2008.

2 (a) S. H. Cho, J. Y. Kim, J. Kwak and S. Chang, Chem. Soc. Rev., 2011, 40, 5068; (b) F. Collet, R. H. Dodd and P. Dauban, Chem. Commun., 2009, 5061; (c) V. S. Thirunavukkarasu, S. I. Kozhushkov and L. Ackermann, Chem. Commun., 2014, 50, 29.

3 For reviews on C-N cross-coupling reactions: $(a)$ I. P. Beletskaya and A. V. Cheprakov, Organometallics, 2012, 31, 7753; (b) J. Bariwalab and E. V. der Eycken, Chem. Soc. Rev., 2013, 42, 9283.

4 Intramolecular amination: (a) W. C. P. Tsang, N. Zheng and S. L. Buchwald, J. Am. Chem. Soc., 2005, 127, 14560; (b) M. Wasa and J.-Q. Yu, J. Am. Chem. Soc., 2008, 130, 14058; (c) J. A. JordanHore, C. C. C. Johansson, M. Gulias, E. M. Beck and M. Gaunt, J. Am. Chem. Soc., 2008, 130, 16184; (d) T.-S. Mei, X. Wang and J.-Q. Yu, J. Am. Chem. Soc., 2009, 131, 10806; (e) J. Neumann, S. Rakshit, T. Dröge and F. Glorius, Angew. Chem., Int. Ed., 2009, 48, 6892; (f) Y. Tan and J. F. Hartwig, J. Am. Chem. Soc., 2010, 132, 3676; $(g)$ E. T. Nadres and O. Daugulis, J. Am. Chem. Soc., 2012, 134, 7; (h) G. He, Y. Zhao, S. Zhang, C. Lu and G. Chen, J. Am. Chem. Soc., 2012, 134, 3; (i) S.-Y. Zhang, G. He, Y. Zhao, K. Wright, W. A. Nack and G. Chen, J. Am. Chem. Soc., 2012, 134, 7313; $(j)$ G. He, C. Lu, Y. Zhao, W. A. Nack and G. Chen, Org. Lett., 2012, 14, 2944.

5 Intermolecular amination: (a) H.-Y. Thu, W.-Y. Yu and C.-M. Che, J. Am. Chem. Soc., 2006, 128, 9048; (b) K.-H. Ng, A. S. C. Chan and W.-Y. Yu, J. Am. Chem. Soc., 2010, 132, 12862; (c) B. Xiao, T.-J. Gong, J. Xu, Z.-J. Liu and L. Liu, J. Am. Chem. Soc., 2011, 133, 1466; (d) E. J. Yoo, S. Ma, T.-S. Mei, K. S. L. Chan and J.-Q. Yu, J. Am. Chem. Soc., 2011, 133, 7652; (e) K. Sun, Y. Li, T. Xiong, J. Zhang and Q. Zhang, J. Am. Chem. Soc., 2011, 133, 1694; $(f)$ R. Shrestha, P. Mukherjee, Y. Tan, Z. C. Litman and J. F. Hartwig, J. Am. Chem. Soc., 2013, 135, 8480.

6 X. Chen, X.-S. Hao, C. E. Goodhue and J.-Q. Yu, J. Am. Chem. Soc., $2006,128,6790$.

7 (a) G. Brasche and S. L. Buchwald, Angew. Chem., Int. Ed., 2008, 47, 1932; (b) H. Wang, Y. Wang, C. Peng, J. Zhang and Q. Zhu, J. Am. Chem. Soc., 2010, 132, 13217; (c) S. H. Cho, J. Yoon and S. Chang, J. Am. Chem. Soc., 2011, 133, 5996; (d) J. Lu, Y. Jin, H. Liu, Y. Jiang and $\mathrm{H}$. Fu, Org. Lett., 2011, 13, 3694; (e) X. Wang, Y. Jin, Y. Zhao, L. Zhu and H. Fu, Org. Lett., 2012, 15, 452.

8 For reviews: (a) A. Armstrong and J. C. Collins, Angew. Chem., Int. Ed., 2010, 49, 2282; (b) M. Zhang, Synthesis, 2011, 3408.

9 (a) Q. Wang and S. L. Schreiber, Org. Lett., 2009, 11, 5178; (b) D. Monguchi, T. Fujiwara, H. Furukawa and A. Mori, Org. Lett., 2009, 11, 1607; (c) M. Miyasaka, K. Hirano, T. Satoh, R. Kowalczyk, C. Bolm and M. Miura, Org. Lett., 2011, 13, 359; (d) G. Li, C. Jia and K. Sun, Org. Lett., 2013, 15, 5198.

10 (a) T. Uemura, S. Imoto and N. Chatani, Chem. Lett., 2006, 35, 842; (b) Q. Shuai, G. Deng, Z. Chua, D. S. Bohle and C.-J. Li, Adv. Synth. Catal., 2010, 352, 632; (c) A. John and K. M. Nicholas, J. Org. Chem., 2011, 76, 4158.

11 See also: (a) J. Gallardo-Donaire and R. Martin, J. Am. Chem. Soc., 2013, 135, 9350; (b) J. Roane and O. Daugulis, Org. Lett., 2013, 15, 5842.

12 L. D. Tran, J. Roane and O. Daugulis, Angew. Chem., Int. Ed., 2013, 52, 6043.

13 B. Urones, A. M. Martínez, N. Rodríguez, R. G. Arrayás and J. C. Carretero, Chem. Commun., 2013, 44, 11044.

14 (a) A. García-Rubia, B. Urones, R. Gómez Arrayás and J. C. Carretero, Angew. Chem., Int. Ed., 2011, 50, 10927; (b) N. Rodríguez, J. A. Romero-Revilla, M. A. Fernández-Ibáñez and J. C. Carretero, Chem. Sci., 2013, 4, 175; (c) B. Urones, R. Gómez Arrayás and J. C. Carretero, Org. Lett., 2013, 15, 1120.

15 For COPy-assisted C-H reactions: (a) V. G. Zaitsev, D. Shabashov and O. Daugulis, J. Am. Chem. Soc., 2005, 127, 13154; (b) F.-R. Gou, X.-C. Wang, P.-F. Huo, H.-P. Bi, Z.-H. Guan and Y.-M. Liang, Org. Lett., 2009, 11, 5726; (c) G. He and G. Chen, Angew. Chem., Int. Ed., 2011, 50, 5192; (d) Y. Zhao and G. Chen, Org. Lett., 2011, 13, 4850; (e) L. D. Tran, I. Popov and O. Daugulis, J. Am. Chem. Soc., 2012, 134, 18237; $(f)$ Y. Zhao, G. He, W. A. Nack and G. Chen, Org. Lett., 2012, 14, 2948; $(g)$ S.-Y. Zhang, G. He, W. A. Nack, Y. Zhao, Q. Li and G. Chen, J. Am. Chem. Soc., 2013, 135, 2124; $(h)$ E. T. Nadres, G. I. F. Santos, D. Shabashov and O. Daugulis, J. Org. Chem., 2013, 78, 9689; (i) R. Odani, K. Hirano, T. Satoh and M. Miura, J. Org. Chem., 2013, 78, 11045.

$16 \mathrm{PhI}(\mathrm{OAc})_{2}$ alone (without $\mathrm{Cu}$ ) provided no aminated product. No $\mathrm{C}-\mathrm{H}$ oxygenation products were observed under our catalyst system. 17 M. D. Nair and R. Adams, J. Am. Chem. Soc., 1961, 83, 3518.

18 Cu-catalyzed C-H reaction via SET: (a) C. Zhang, C. Tang and N. Jiao, Chem. Soc. Rev., 2012, 41, 3464; (b) A. M. Suess, M. Z. Ertem, C. J. Cramer and S. S. Stahl, J. Am. Chem. Soc., 2013, 135, 979. 